\title{
VEGF gene rs35569394 polymorphism in patients with Polycystic Ovary Syndrome
}

\author{
(iD) Sheila Silveira Fernandes ${ }^{1}$ \\ Alessandra Bernadete Trovó de Marqui ${ }^{2}$ \\ (iD) Daniela Reis Fernandes Teles ${ }^{3}$ \\ DElisabete Aparecida Montovani Rodrigues Resende \\ (iD) Marco Fábio Prata Lima ${ }^{5}$ \\ Mariana Kefalas Oliveira Gomes ${ }^{5}$ \\ (D) Mariangela Torreglosa Ruiz Cintra ${ }^{6}$
}

\begin{abstract}
1. Graduada em Ciências Biológicas pela Universidade Federal do Triângulo Mineiro/UFTM, Uberaba, MG, Brasil 2. Professora do Instituto de Ciências Biológicas e Naturais (ICBN) da UFTM, Uberaba, MG, Brasil 3. Tecnóloga do Curso de Ciências Biológicas do Instituto de Ciências Exatas, Naturais e Educação - ICENE da UFTM, Uberaba, MG, Brasil 4. Professora do Instituto de Ciências e Saúde (ICS) da UFTM, Uberaba, MG, Brasil 5. Professor do Instituto de Ciências e Saúde (ICS) da UFTM, Uberaba, MG, Brasil 6. Professora do ICENE da UFTM, Uberaba, MG, Brasil
\end{abstract}

http://dx.doi.org/10.1590/1806-9282.66.10.1396

\section{SUMMARY}

OBJECTIVE: The relationship between the clinicopathological and sociodemographics characteristics of acral melanomas diagnosed at BACKGROUND: This study aimed to investigate the frequency of VEGF gene insertion (I) / deletion (D) polymorphism (rs35569394) in patients with Polycystic Ovarian Syndrome (PCOS) and to compare with a control population to verify its association with the pathology.

METHODS: 206 women participated in this study, 103 with PCOS (group of patients) and 103 without the disease (control group). After extraction of genomic DNA from the samples, molecular analysis was performed by Polymerase Chain Reaction (PCR) and electrophoresis in polycrylamide. Descriptive analysis, univariate analysis and logistic regression model were used. Results were presented in odds ratio $(O R)$ and $95 \%$ confidence interval $(95 \% \mathrm{Cl})$, considering the significance of $p<0.05$.

RESULTS: There were no statistical differences between patients and controls for allele frequencies $(\chi 2=1.16, p=0.56)$. The genotypic frequency distribution was in Hardy Weinberg equilibrium for the patients $(\chi 2=2.42 ; p<0.05)$, but not for the control group ( $\chi 2=7.26$; $p<0.05)$. Regarding risk factors for the syndrome, a history of familial PCOS is more frequent among women with the syndrome.

CONCLUSIONS: In the present study, there is no association between VEGF gene I / D polymorphism and PCOS.

KEYWORDS: Polycystic ovary syndrome. Polymorphism, Genetic. Polymerase chain reaction.

\section{INTRODUCTION}

Polycystic Ovary Syndrome (PCOS) is an endocrine metabolic pathology that affects $5 \%$ to $20 \%$ of women of reproductive age and is considered one of the main causes of female infertility. ${ }^{1}$ The diagnosis of this condition is based on the Rotterdam criteria that consists of at least two of the following three findings: (1) oligoovulation or chronic anovulation, (2) clinical and/or laboratory evidence of hyperandrogenism and (3) pelvic ultrasound indicative of polycystic ovaries. ${ }^{2}$ Secondary manifestations may also

DATE OF SUBMISSION: 20-May-2020

DATE OF ACCEPTANCE: 01-Jun-2020

CORRESPONDING AUTHOR: Mariangela Torreglosa Ruiz Cintra

Instituto de Ciências Exatas, Naturais e Educação - ICENE - Universidade Federal do Triângulo Mineiro - UFTM

Av. Dr. Randolfo Borges Jr. 1400 - Univerdecidade - Uberaba - MG - 38064-200 - Tel: (34) 3331-3143

Email: mariangela.cintra@uftm.edu.br 
occur, such as metabolic disorders related to obesity, insulin resistance, type II diabetes mellitus, cardiovascular disease, endometrial carcinoma and dyslipidemia. Women with PCOS are also at increased risk for gestational diabetes, pre-eclampsia and pregnancy complications with early pregnancy loss and / or neonatal complications. ${ }^{3}$

PCOS is a multifactorial disease and studies show that genetic predisposition and exposureto environmental factors such as toxins, diet, nutrition and ethnicity are in the etiology of this pathology. ${ }^{3,4}$

Among the genes studied in PCOS, changes in the Vascular Endothelial Growth Factor/VEGF gene, which encodes a protein that participates in the physiological regulation of ovarian angiogenesis, stabilization of blood vessels, formation, function and regression of the corpus luteum, can play an important role in the etiology of the syndrome. ${ }^{5}$ The correct formation and regression of vascular vessels during each ovarian cycle is important for proper follicular development, ovulation and formation of the corpus luteum. The small follicles are avascular and depend on stromal vessels for nutrition and hormonal supply. Blood vessels develop within the ovarian theca, regulated by angiogenic factors, and each follicle depends on its thecal vascular pathway to survive and mature. ${ }^{1}$ Studies have shown an association of alterations in the VEGF gene when abnormalities occur in the angiogenesis process. ${ }^{6,7}$ Another study also showed that changes in ovarian angiogenesis in different gynecological conditions may contribute to an increased risk of ovulation disorders, hyperandrogenism and infertility, which are characteristics of PCOS. ${ }^{5}$

This gene is highly polymorphic and is located in the chromosomal region 6p21.3.It consists of eight exons and seven introns, exhibiting alternative splicing to form a family of proteins. ${ }^{6}$ An 18 base pair insertion/deletion (I/D) polymorphism was located in the promoter region at position -2549 of the VEGFA gene (rs35569394). This alteration affects the gene expression and the increased transcriptional activity by allele D (deletion) compared to allele I (insertion). ${ }^{8}$ This genetic variant was associated to some gynecological conditions, such as risk of recurrent spontaneous abortion, ${ }^{8}$ severe pre-eclampsia, ${ }^{9}$ uterine leiomyoma ${ }^{10}$ and susceptibility to breast cancer. ${ }^{11}$ However, recent bibliographic surveys do not show published data on the rs35569394 polymorphism in PCOS. In spite of that, it is known that patients with PCOS have increased VEGF protein expression and VEGF polymorphisms contribute to the etiology of this endocrine metabolic condition. ${ }^{7,12-15}$ Recent studies conducted by our group have shown that the VEGF gene rs1570360 polymorphism is associated with PCOS and the TGC haplotype may be associated with protective factors. ${ }^{13}$ A meta-analysis included 29 case-control studies of 11 polymorphisms of the VEGF gene and concluded that such genetic variants may become early biomarkers of PCOS. ${ }^{16}$

In view of the above, this study aimed to determine the frequency of the polymorphism of the VEGF gene (rs3569394) in patients with PCOS and to compare it with a control population in order to verify the association of this polymorphism with the syndrome.

\section{METHODS}

This is a case-control study approved by the Research Ethics Committee (CEP) of the Federal University of Triângulo Mineiro (UFTM), protocol $\mathrm{n}^{\circ}$ 1796. The sample consisted of 206 women from the Gynecology and Obstetrics Clinics at UFTM, 103 diagnosed with PCOS and 103 women of reproductive age, between 14 and 53 years old, with no history of hyperandrogenism, menstrual dysfunction, infertility or sonographic sign of PCOS, metabolic disorders, which constituted the control group.

Rotterdam criteria were used for the diagnosis of PCOS. Exclusion criteria were applied to women with Cushing's syndrome, 21-hydroxylase deficiency, thyroid dysfunction, hyperprolactinemia, diabetes, androgen-secreting tumors, antiandrogens, statins, glucocorticoids or infertility medications. Patients with the mentioned pathologies or in use of these drugs were excluded from the sample, as these conditions may cause hormonal changes and be conflicting factors for the diagnosis of PCOS. The patients were considered "smokers" when at least 100 cigarettes were consumed during their lifetime. With regards to alcohol, those who consume at least four doses per week were considered "alcohol users".."

The genomic DNA was extracted from $5 \mathrm{~mL}$ of peripheral blood using the salting-out procedure, described by Miller et al. (1988) ${ }^{18}$. This technique is fast, simple and very efficient for obtaining high quality DNA. The quantification of genomic DNA was performed by spectrophotometry and the ratio between the A260 / A280 readings was approximately to 1.8. The rs 35569394 polymorphism was analysed by Polymerase Chain Reaction (PCR) using the following 
sequences of the primers sense 5'GCT GAG AGT GGG GCT GAC GAG TAG GTA 3’ and antisense 5 ‘GTT TCT GAC CTG GCT ATT TCC AGG 3'.

The genomic DNA was amplified in a final volume of $25 \mu \mathrm{L}$ containing approximately $100 \mathrm{ng}$ of genomic DNA, 1X PCR buffer, 2m M of MgCl2, 2 uM de dNTP and $1 \mathrm{U}$ of Taq DNA polymerase (Invitrogen, Brasil). To the reaction, 20 pmol of each primer (Exxtend, Brasil) were also used. All PCR experiments were performed with negative control, that is, the components of the reaction without genomic DNA. Amplification conditions were: initial denaturation at $95^{\circ} \mathrm{C}$ for 10 minutes, followed by 35 cycles with denaturation at $95^{\circ} \mathrm{C}$ for 45 seconds, annealing at $60^{\circ} \mathrm{C}$ for 45 seconds, extension at $72^{\circ} \mathrm{C}$ for 45 seconds and final extension at $72^{\circ} \mathrm{C}$ for 10 minutes. PCR products were visualized on $10 \%$ polycrylamide gel, coloured with ethidium bromide for 10 minutes and visualized in UV light for genetic determination, with the $229 \mathrm{bp}$ products corresponding to the insertion of $18 \mathrm{bp}$ (allele I) and the $211 \mathrm{bp}$ the deletion (allele D). Thus, three genotypes can be found: II (one band in the electroforesis of $229 \mathrm{bp}$ ), ID (two bands, one of $229 \mathrm{bp}$ and other of $211 \mathrm{bp}$ ) and DD (one band of $211 \mathrm{bp}$ ) (Figure 1).

FIGURE 1. PCR AMPLIFICATION PATTERNS FOR GENOTYPES II (A SINGLE BAND OF 229 BP IN THE ELECTROPHORESIS), ID (TWO BANDS, ONE WITH 229 BP AND THE OTHER WITH 211 BP) AND DD (ONE 211 BP BAND) IN ONE 10\% POLYACRYLAMIDE GEL STAINED WITH ETHIDIUM BROMIDE. COLUMN 5 REPRESENTS GENOTYPE II; COLUMNS 2, 3, 4 AND 7 REPRESENT THE HETEROZYGOUS ID GENOTYPE AND COLUMNS 1 AND 6, THE DD GENOTYPE.

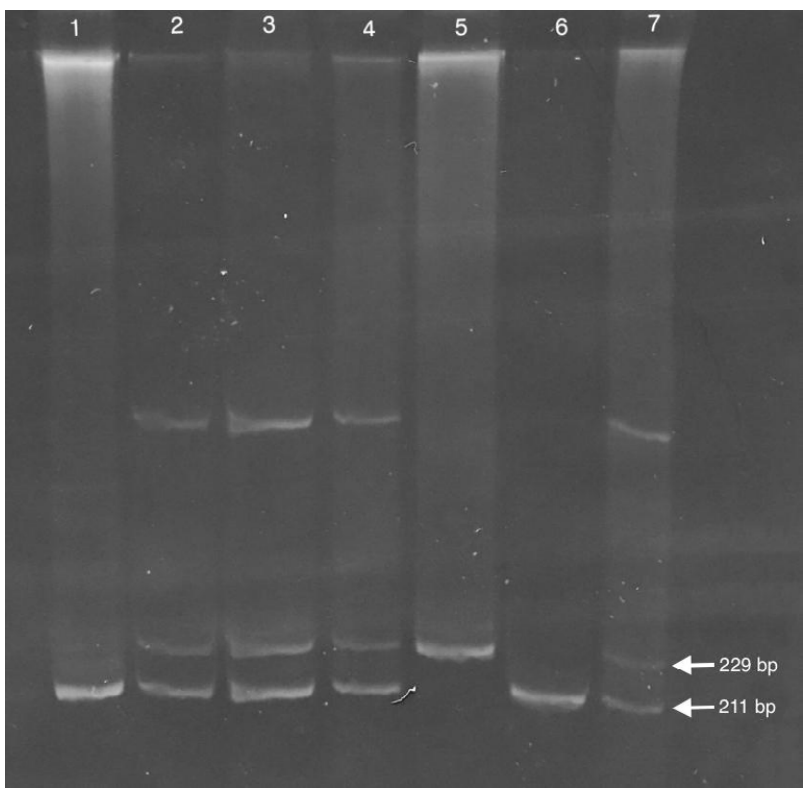

In the statistical analysis, the chi-square test was used to analyse the genotypic and allelic distribution of the polymorphisms and the Hardy Weinberg equilibrium was also tested by the same test, considering the significance of $\mathrm{p}<0.05$. The multiple logistic regression model was used to determine the effect of risk factors on PCOS (family history of PCOS, smoking, alcoholism and the presence of polymorphism) and was analysed in 94 patients and 83 controls who had complete data for all variables analysed. Multiple logistic regression was performed only for the patients and the model included the clinical consequences of PCOS and the polymorphism studied.

\section{RESULTS}

In the control group ( $\mathrm{n}=103), 6.8 \%(7 / 103)$ had genotype II, 58.2\% (60/103) had ID genotype and 35\% (36/103) presented the DD genotype. In the patients group ( $n=103)$, the genotype frequencies were $9.7 \%$ (10/103); 53.3\% (55/103) and 37\% (38/103), for genotypes II, ID and DD, respectively. No statistical differences were observed between patients and controls for genotype frequencies $(\chi 2=0.80 ; p=0.67)$. Allelic

TABLE 1. DISTRIBUTION OF POLYMORPHISM OF RS35569394 OF VEGF GENE AND RISK FACTORS IN PATIENTS WITH POLYCYSTIC OVARY SYNDROME (PCOS, $N=94$ ) AND CONTROLS (SPCOS, $N=93$ ), THAT HAD COMPLETE DATA FOR THE ANALYZED VARIABLES.

\begin{tabular}{|c|c|c|c|c|}
\hline $\begin{array}{l}\text { VARIABLE } \\
\text { ANALYZED }\end{array}$ & $\begin{array}{l}\text { PCOS n } \\
(\%)\end{array}$ & $\begin{array}{l}\text { CPCOS n } \\
(\%)\end{array}$ & $\begin{array}{l}\text { O.R } \\
(\mathrm{Cl}-95 \%)\end{array}$ & $\mathrm{p}$ \\
\hline Smoker & & & & $<0.05$ \\
\hline Yes & 06 (6.38) & 21 (28.09) & \multirow{2}{*}{$\begin{array}{l}0.28 \\
(0.10-0.78)\end{array}$} & \\
\hline No & $88(93.62)$ & $72(71.91)$ & & \\
\hline $\begin{array}{l}\text { Alcohol con- } \\
\text { sumption }\end{array}$ & & & & 0.68 \\
\hline Yes & 25 (26.59) & $31(33.33)$ & \multirow{2}{*}{$\begin{array}{l}0.86 \\
(0.43-1.73)\end{array}$} & \\
\hline No & 69 (73.41) & $62(66.64)$ & & \\
\hline $\begin{array}{l}\text { PCOS Family } \\
\text { History }\end{array}$ & & & $\begin{array}{l}3.87 \\
(1.85-8.11)\end{array}$ & $<0.05$ \\
\hline Yes & $38(40.42)$ & $15(16.13)$ & \multirow{5}{*}{$\begin{array}{l}0.89 \\
(0.30-2.62)\end{array}$} & \\
\hline No & $56(59.58)$ & 78 (83.87) & & \\
\hline $\begin{array}{l}\text { Polimorphism of } \\
\text { VEGF gene }\end{array}$ & & & & 0.83 \\
\hline II & $9(9.57)$ & $7(7.52)$ & & \\
\hline ID/DD & $85(90.43)$ & $86(92.48)$ & & \\
\hline
\end{tabular}


TABLE 2. DISTRIBUTION OF POLYMORPHISM OF RS35569394 OF VEGF GENE AND CLINICAL OUTCOMES IN PATIENTS ( $N=94)$ WITH GENOTYPE II VERSUS PATIENTS WITH GENOTYPES ID OU DD.

\begin{tabular}{|c|c|c|c|c|}
\hline $\begin{array}{l}\text { VARIABLE } \\
\text { ANALYZED }\end{array}$ & $\begin{array}{l}\text { Patients } \\
\text { with geno- } \\
\text { type } \\
\text { II, n (\%) }\end{array}$ & $\begin{array}{l}\text { Patiens with } \\
\text { genotypes } \\
\text { ID or DD, n } \\
(\%)\end{array}$ & $\begin{array}{l}\text { O.R (Cl } \\
95 \%)\end{array}$ & $\mathrm{p}$ \\
\hline $\begin{array}{l}\text { Absence of } \\
\text { Pregnancy }\end{array}$ & & & $\begin{array}{l}3.60(0.26- \\
48.89)\end{array}$ & \\
\hline Yes & $02(22.2)$ & $65(76.5)$ & & 0.33 \\
\hline No & $07(77.8)$ & $20(23.5)$ & & \\
\hline Abortation & & & $\begin{array}{l}0.21(0.12- \\
3.86)\end{array}$ & \\
\hline Yes & 01 (11.1) & 05 (5.9) & & 0.30 \\
\hline No & $08(88.9)$ & $80(94.1)$ & & \\
\hline $\begin{array}{l}\text { Menstrual } \\
\text { Irregularity }\end{array}$ & & & $\begin{array}{l}2.83(0.47- \\
16.76)\end{array}$ & 0.25 \\
\hline Yes & $04(44.4)$ & $54(63.5)$ & & \\
\hline No & 05 (55.6) & $31(36.5)$ & & \\
\hline Hirsutism & & & $\begin{array}{l}3.20(0.55- \\
18.47)\end{array}$ & 0.19 \\
\hline Yes & $03(33.3)$ & $51(60)$ & & \\
\hline No & $06(66.7)$ & $34(40)$ & & \\
\hline Acne & & & $\begin{array}{l}1.19(0.17- \\
8.10)\end{array}$ & 0.85 \\
\hline Yes & $04(44.4)$ & $55(64.9)$ & & \\
\hline No & 05 (55.6) & $30(35.1)$ & & \\
\hline Oiliness & & & $\begin{array}{l}1.44(0.12- \\
16.40)\end{array}$ & 0.76 \\
\hline Yes & $07(77.8)$ & $64(75.3)$ & & \\
\hline No & $02(22.2)$ & $21(24.7)$ & & \\
\hline Hair Loss & & & $\begin{array}{l}1.42(0.23- \\
8.71)\end{array}$ & 0.70 \\
\hline Yes & $04(44.4)$ & $56(65.9)$ & & \\
\hline No & $05(55.6)$ & $29(34.1)$ & & \\
\hline
\end{tabular}

TABLE 3. RECENT STUDIES PUBLISHED IN THE LITERATURE ON THE VEGF - 2549 I / D POLYMORPHISM IN DIFFERENT GYNECOLOGICAL CONDITIONS.

\begin{tabular}{l|l|l} 
Author & Condition & Conclusion \\
\hline $\begin{array}{l}\text { Keshavarzi et al., } \\
(2017)^{\mathbf{1 0}}\end{array}$ & $\begin{array}{l}\text { Uterine leiomy- } \\
\text { omas }\end{array}$ & $\begin{array}{l}\text { Significant association } \\
\text { between genotype II. }\end{array}$ \\
\hline Bruno et al., (2018) & Endometriosis & $\begin{array}{l}\text { Variant was not } \\
\text { associated with the } \\
\text { investigated condition. }\end{array}$ \\
\hline $\begin{array}{l}\text { Hashemi et al., } \\
(2018)^{\mathbf{8}}\end{array}$ & $\begin{array}{l}\text { Recurrent sponta- } \\
\text { neous abortion }\end{array}$ & $\begin{array}{l}\text { Significant association } \\
\text { between polymor- } \\
\text { phism and the risk of } \\
\text { recurrent miscarriage. }\end{array}$ \\
\hline $\begin{array}{l}\text { Gala-Bladzinska et } \\
\text { al.., (2019) }\end{array}$ & $\begin{array}{l}\text { Vascular compli- } \\
\text { cations in patients } \\
\text { with type 2 diabe- } \\
\text { tes mellitus }\end{array}$ & $\begin{array}{l}\text { The presence of the } \\
\text { I/ D allele may be } \\
\text { associated with heart } \\
\text { failure and strokes. }\end{array}$ \\
\hline $\begin{array}{l}\text { Keshavarzi et al., } \\
\text { (2019) }\end{array}$ & Pre eclampsia & $\begin{array}{l}\text { No association was } \\
\text { found between the } \\
\text { studied polymor- } \\
\text { phisms. }\end{array}$ \\
\hline $\begin{array}{l}\text { Vidyadhari et al., } \\
\text { (2019) }\end{array}$ & $\begin{array}{l}\text { Recurrent pregnan- } \\
\text { cy loss }\end{array}$ & $\begin{array}{l}\text { Polymorphism was } \\
\text { associated with abort- } \\
\text { ed fetuses. }\end{array}$ \\
\hline
\end{tabular}

frequencies were 0.36 and 0.64 for alleles I and D in both groups. The distribution of genotypic frequencies was in HWE to the patients $(\chi 2=2.42 ; \mathrm{p}<0.12)$, but not to the control group $(\chi 2=7.26 ; p<0.05)$. There were also no differences between allele frequencies $(\chi 2=1.16, p=0.56)$.

In the multiple logistic regression model (Table 1) it was evidenced that family history was more frequent in patients with PCOS (OR=3.87, 95\% CI: 1.858.11, $\mathrm{p}<0.05)$, smoking was more frequent in controls (OR=0.28; 95\% CI: 0.10-0.78, $\mathrm{p}<0.05)$ and there were no differences in alcohol consumption $(\mathrm{OR}=0.86$, 95\% CI: 0.43.1.73, $\mathrm{p}=0.68$ ) and in the distribution of polymorphism (OR=0.89, 95\% CI: 0.30-2.62, $\mathrm{p}=0.83$ ). There were no differences between patients with the presence of polymorphism and clinical consequences of disease (Table 2).

\section{DISCUSSION}

The VEGF gene is expressed and secreted in the human ovary and plays an important role in the folliculogenesis of the ovarian cycle. Deregulation of ovarian angiogenesis contributes to abnormal follicular development in women with PCOS, with an imbalance in angiogenic factors. ${ }^{1}$ Two recent studies evaluated polymorphisms of the VEGF gene in patients with PCOS, one of which evaluated Single Nucleotide Polymorphisms/SNPs in 55 patients and 52 controls $^{12}$ and the other, two SNPs (rs2010963 and rs833061) in 118 and 130 patients and controls, respectively ${ }^{14}$. Both confirmed the participation of genetic variants of the VEGF gene for the pathogenesis of the syndrome. However, there are no published studies on the contribution of the rs35569394 polymorphism of the VEGF gene to the development of PCOS. In addition, a previous study conducted by our group also showed that the rs1570360 polymorphism is associated with PCOS and the TGC haplotype is associated with protective factors ${ }^{13}$, which made us investigate the contribution of this other SNP of the VEGF gene to the development of this condition.

The absence of studies of this SNP in PCOS makes it difficult to discuss the results obtained, but it highlights the originality of our research. In the present study, according to the univariate analysis (103 patients and 103 controls), the rs35569394 polymorphism did not show statistically significant differences in the distribution of genotypic frequencies between patients with PCOS and controls. Similar results have been reported in other studies conducted 
in patients with endometriosis ${ }^{19}$ and hepatocellular carcinoma. ${ }^{20}$ The present study observed that the genotypic frequency of the control group was not in HWE as in the study by Bruno and collaborators in $2018^{19}$, which suggests a protective effect of the polymorphic allele.

It has been reported that the presence of the $\mathrm{D}$ allele in the -2549 promoter region leads to a 1.95fold increase in transcriptional activity, increasing the expression of VEGF. ${ }^{8}$ Our results showed high frequencies in both ID and DD genotypes, and the literature has associated the frequency of the $\mathrm{D}$ allele to cases of diabetic nephropathy ${ }^{21}$ and severe pre-eclampsia. ${ }^{9}$ According to previous research ${ }^{22}$, the inheritance of the D allele can alter the VEGFA in the gene expression of the embryo, causing abnormalities in protein levels that may lead to spontaneous abortion and abnormal angiogenesis. However, it is important to highlight that there are controversies regarding the potential of the $\mathrm{D}$ allele as a risk factor for clinical conditions, since a published study positively associated genotype II and/or allele I with pathologies such as uterine leiomyoma. ${ }^{10}$

The increase in the frequency of smoking in the control group is not in accordance with a previous study ${ }^{23}$, in which women with PCOS showed higher frequency in relation to smoking, as well as a greater risk of worsening the metabolic profile. The increased frequency of family recurrence of PCOS in the study group is supported by the literature that evidences genetic factors in the etiology of this pathology, leading to a shared genetic predisposition. ${ }^{3}$ The risk factors established for PCOS are related to the increased risk to develop infertility, cardiovascular disease, metabolic syndrome, type 2 diabetes and endometrial cancer. Pregnant women with PCOS have a higher risk of pregnancy complications, such as pre-eclampsia, spontaneous abortion, gestational diabetes and premature birth. ${ }^{1}$ No differences were found between clinical manifestations of PCOS and the analyzed polymorphism. It is known that hyperandrogenism is characterized by an increase in the production of ovarian androgen due to the increased synthesis of the hormone by follicular theca cells, which shows an increased expression of several genes that encode these steroids. ${ }^{3}$ However, in the study analyzed, no associations were found between these parameters and the investigated polymorphism.
PCOS is multifactorial and the presence of the $D$ allele can be a risk factor for the clinical consequences of the pathology, as it leads to the overproduction of androgen hormones responsible for the clinical manifestations of this condition, such as menstrual irregularity, acne, hirsutism, polycystic ovarian morphology, insulin resistance and obesity. ${ }^{1,3}$ The literature reports that the high vascularization promoted by high levels of VEGF in the stroma can lead to abnormal growth of the theca - an important site for androgenic steroidogenesis. ${ }^{6}$

In the present study, this genetic polymorphism was not associated with PCOS. However, previous studies on other gynecological conditions have shown divergent results (Table 3).

The present study faced a certain limitation because there was no dosage of the various biochemical parameters related to PCOS and VEGF serum levels to assess the association between genotypes. However, it is important mentioning that our study so far is the only one to evaluate this polymorphism in PCOS and, although it has not been individually associated with PCOS, the study in (of?) haplotypes may present significant effects. Previous studies ${ }^{13,25}$ show the importance of this type of analysis to help understanding the etiology of complex diseases. In conclusion, the VEGF -2549 I/D polymorphism is not associated with PCOS in the investigated sample.

\section{Financial Suport}

Pró- Reitoria de Pesquisa e Pós-Graduação - Universidade Federal do Triângulo Mineiro (Edital no. 31/2017) e Fundação de Amparo à Pesquisa do Estado de Minas Gerais - FAPEMIG - (Processo APQ 01608-14).

\section{Authors' contributions}

Sheila Silveira Fernandes: project design, data collection and analysis, article writing; Alessandra Bernadete Trovó de Marqui: project design, data collection and analysis, article writing; Daniela Reis Fernandes Teles: data collection and analysis; Elisabete Aparecida Montovani Rodrigues Resende: data collection and analysis; Marco Fábio Prata Lima: data collection and analysis; Mariana Kefalas Oliveira Gomes: data collection and analysis; Mariangela Torreglosa Ruiz Cintra: project design, data collection and analysis, article writing. All authors participated in the final analysis of the article. 


\section{RESUMO}

OBJETIVO: Este estudo teve como objetivo investigar a frequência do polimorfismo de inserção (I)/ deleção (D) do gene VEGF (rs35569394) em pacientes com Síndrome dos Ovários Policísticos (SOP) e comparar com uma população controle para verificar sua associação com a patologia.

MÉTODOS: Participaram desse estudo 206 mulheres sendo 103 com SOP (grupo de pacientes) e 103 sem a doença (grupo controle). Após extração do DNA genômico das amostras, a análise molecular foi realizada por Reação em Cadeia da Polimerase e eletroforese em gel de poliacrilamida. Utilizou-se análise descritiva, análise univariada e modelo de regressão logística. Os resultados foram apresentados em odds ratio (OR) e intervalo de confiança de 95\% (IC-95\%), considerando a significância de p<0,05.

RESULTADOS: Não houve diferenças estatísticas entre as pacientes e controles para as frequências alélicas $(\chi 2=1,16, p=0,56)$. A distribuição da frequência genotípica estava em equilíbrio de Hardy Weinberg para as pacientes $(\chi 2=2,42 ; p<0,12)$, mas não para o grupo controle $(\chi 2=7,26 ; p<0,05)$. Em relação aos fatores de risco para a síndrome, a história de SOP familiar é mais frequente entre as mulheres com a síndrome.

CONCLUSÕES: Na casuística estudada, não há associação entre o polimorfismo I/D do gene da VEGF e a SOP.

PALAVRAS ChaVe: Síndrome do ovário policístico. Polimorfismo genético. Reação em cadeia da polimerase.

\section{REFERENCES}

1. Di Pietro M, Pascuali N, Parborell F, Abramovich D. Ovarian angiogenesis in polycystic ovary syndrome. Reproduction. 2018;155(5):R199-R209.

2. Rotterdam ESHRE/ASRM-Sponsored PCOS consensus workshop group. Revised 2003 consensus on diagnostic criteria and long-term health risks related to polycystic ovary syndrome (PCOS). Hum Reprod. 2004;19(1):41-7.

3. Azziz R, Carmina E, Chen Z, Dunaif A, Laven JSE, Legro RS, et al. Polycystic ovary syndrome. Nat Rev Dis Primers. 2016;2:16057.

4. Kshetrimayum C, Sharma A, Mishra VV, Kumar S. Polycystic ovarian syndrome: environmental/occupational, lifestyle factors - an overview. J Turk Ger Gynecol Assoc. 2019;20(4):255-63.

5. Tal R, Seifer DB, Arici A. The emerging role of angiogenic factor dysregulation in the pathogenesis of polycystic ovarian syndrome. Semin Reprod Med. 2015;33(3):193-207.

6. Guruvaiah, P, Govatati S, Reddy TV, Lomada D, Deenadayal M, Shivaji $\mathrm{S}$, et al. The VEGF $+405 \mathrm{G}>\mathrm{C} 5^{\prime}$ untranslated region polymorphism and risk of PCOS: a study in the South Indian Women. J Assist Reprod Genet. 2014;31(10):1383-9.

7. Almawi WY, Gammoh E, Malalla ZH, Al-Madhi SA. Analysis of VEGFA variants and changes in VEGF levels underscores the contribution of VEGF to polycystic ovary syndrome. PloS One. 2016;11(11):e0165636.

8. Hashemi M, Danesh H, Bizhani F, Mokhtari M, Bahari G, Tabasi F, et al. The -2549 insertion/deletion polymorphism in the promoter region of VEGF is associated with the risk of recurrent spontaneous abortion. Biomed Rep. 2018;8(3):297-300

9. Keshavarzi F, Shahrakipoor M, Teimoori B, Yaghmaei M, Narooei-Nejad $M$, Rasooli A, et al. Association of the placental VEGF promoter polymorphisms and VEGF mRNA expression with preeclampsia. Clin Exp Hypertens. 2019;41(3):274-9.

10. Keshavarzi F, Salimi S, Mohammadpour-Gharehbagh A, Teimoori B, Yazdi A, Farajian-Mashhadi F, et al. The -2549 insertion/deletion polymorphism of VEGF gene associated with uterine leiomyoma susceptibility in women from Southeastern Iran. Ginekol Pol. 2017;88(3):115-9.

11. Kapahi R, Manjari M, Uppal MS, Singh NR, Sambyal V, Guleria K. Association of -2549 insertion/deletion polymorphism of vascular endotelial growth fator with breast cancer in North Indian patients. Genet Test Mol Biomarkers. 2013;17(3):242-8.

12. Bao L, Syed R, Aloahd MS. Analysis of VEGF gene polymorphisms and serum VEGF protein levels contribution in polycystic ovary syndrome of patients. Mol Biol Rep. 2019;46(6):5821-9.

13. Gomes MKO, Antonino DC, Balarin MAS, Tanaka SCSV, Caldeira MA, Trovó de Marqui $A B$, et al. Haplotype analysis of VEGF gene polymorphisms in polycystic ovary syndrome. Gynecol Endocrinol. 2019:35(10):847-50.

14. Huang X, Hao YL, Zhen XL, Zhou RM, Wang N, Cao SR, et al. Association between the vascular endothelial growth factor gene polymorphisms and the risk of polycystic ovary syndrome in Northern Chinese Women. Gynecol Endocrinol. 2019;35(8):706-9.

15. Ben Salem A, Megdich F, Kacem O, Souayeh M, Hachani Ben Ali F, Hizem $S$, et al. Vascular endothelial growth factor (VEGFA) gene variation in polycystic ovary syndrome in a Tunisian women population. BMC Genomics. 2016;17(Suppl 9):748.

16. Huang L, Wang L. Association between VEGF gene polymorphisms (11 sites) and polycystic ovary syndrome risk. Biosci Rep. 2020;40(3):BSR20191691.

17. Fassio E, Díaz S, Santa C, Reig ME, Martínez Artola Y, Alves de Mattos A, et al: Multicenter Group for Study of Hepatocarcinoma in Latin America; Asociación Latinoamericana para el Estudio del Hígado (ALEH). Etiology of hepatocellular carcinoma in Latin America: a prospective, multicenter, international study. Ann Hepatol. 2010;9(1):63-9.

18. Miller SA, Dykes DD, Polesky HF. A simple salting out procedure for extracting DNA from human nucleated cells. Nucleic Acids Res. 1988;16(3):1215.

19. Bruno LT, Prata-Lima MF, Ruiz-Cintra M, Marqui ABT. Investigation of VEGF gene polymorphism rs35569394 in endometriosis. J Bras Patol Med Lab. 2018;54(6):359-63.

20. He Y, Ni J, Chen S, Jiang Y, Jia S, Gao Y. The vascular endotelial growth factor-2549 insertion/deletion polymorphism is not associated with susceptibility to hepatocellular carcinoma in Chinese. DNA Cell Biol. 2010;29(7):393-6.

21. Amle D, Mir R, Khaneja A, Agarwal S, Ahlawat R, Ray PC, et al. Association of $18 \mathrm{bp}$ insertion/deletion polymorphism, at -2549 position of VEGF gene, with diabetic nephropathy in type 2 diabetes mellitus patients of North Indian population. J Diabetes Metab Disord. 2015;14:19.

22. Pereza N, Ostojić S, Smirčić A, Hodžić A, Kapović M, Peterlin B. The -2549 insertion/deletion polymorphism in the promoter region of the VEGFA gene in couples with idiopathic recurrent spontaneous abortion. I Assist Reprod Genet. 2015;32(12):1789-94.

23. Glintborg D, Mumm H, Hougaard DM, Ravn P, Andersen M. Smoking is associated with increased adrenal responsiveness, decreased prolactin levels and a more adverse lipid profile in 650 white patients with polycystic ovary syndrome. Gynecol Endocrinol. 2012;28(3):170-4.

24. Gala-Błądzińska A, Czech |, Braun M, Skrzypa M, Gargasz K, Mazur A, et al. Association of 18bp insertion/deletion polymorphism, at -2549 position of VEGF gene, with diabetic vascular complications in type 2 diabetes mellitus. Adv Med Sci. 2019;64(1):137-43.

25. Vidyadhari M, Sujatha M, Krupa P, Nallari P, Venkateshwari A. Association of genetic polymorphism of vascular endothelial growth factor in the etiology of recurrent pregnancy loss: a triad study. | Assist Reprod Genet. 2019:36(5):979-88 